\title{
Anglican Clergy Husbands Securing Middle-Class Gendered Privilege Through Religion
}

Sarah-Jane Page

Aston University

\begin{abstract}
Traditionally, clergy wives have been obliged to assist the Church in an unpaid capacity; such work has been feminised, associated with the assumed competencies of women (Denton 1962; Finch 1980, 1983; Murphy-Geiss 2011). Clergy husbands are a relatively recent phenomenon in the Church of England, emerging when women started to be ordained as deacons in 1987 and priests in 1994. Based on interviews with men whose wives were ordained as priests in the Church of England, this article will explore the dynamics of class and gender privilege. Most clergy husbands were middle class, defined through educational, occupational and cultural markers (Bourdieu 1984). The narratives highlighted how gender and class privilege was maintained and extended through the clergy spouse role. The interweaving dynamics of class and gender privilege secured preferential outcomes for participants, outcomes that were less evidenced in relation to working-class spouses. Using Bourdieu's (1984) concepts of habitus, field and capital and Verter's (2003) conceptualisation of spiritual capital, this article will highlight the complex ways in which gender and class advantage is perpetuated and sustained, using the Anglican parish as the analytical context, thereby emphasising the role religion plays in consolidating privilege.
\end{abstract}

Keywords: Church of England, Bourdieu, Class, Field, Clergy Spouse, Spiritual Capital

\section{Introduction}

Historically, the clergy spouse role was institutionalised, generating expectation from Church and community. Clergy wives have traditionally been expected to undertake various church-based tasks, from teaching Sunday school to running coffee mornings (Denton 1962; Finch 1982; MurphyGeiss 2011). Expectations have lessened as more women enter employment, but the 'clergy spouse' still holds cultural resonance (McMinn et al. 2005; Davies and Guest 2007; Mellow 2007; MurphyGeiss 2011). Clergy husbands are a recent phenomenon in the Church of England, emerging when women started to be ordained firstly as deacons in 1987 then as priests in 1994. This article examines how clergy husbands manage the clergy spouse role, and whether elements of their privileged identity (principally class and gender) impact on this negotiation.

This article is based on interviews with fourteen men who were married to women priests in the Church of England. Most participants were employed in middle-class occupations, where paid 
work brought enormous economic, social and cultural benefit. For the minority of working class spouses, their habitus contrasted with the middle-class church context. They were less-able to utilise the role to their advantage. This article will start by highlighting the theoretical contribution, as well as the limitations, of Bourdieu's (1984; 1987; 1991a) work on religion and class. The article will be methodologically situated, highlighting the ethical dilemmas of studying privilege. Specific attention will be given to how participants were embedded in Bourdieu's framework on class. Two themes will be discussed - how clergy husbands were embedded in the field of paid work and how this affirmed their gendered and classed identities within the parish, and the way clergy husbands deployed spiritual capital in their identity-negotiation. The conclusion will highlight the broader classed context of Anglicanism and how the Church offered a ready repository for clergy husbands to cultivate middleclass gendered privilege.

\section{Bourdieu, Religion and Class}

Bourdieu's (1984) theorisation of social class pertains to the constitutive elements of field, habitus and capital (e.g. economic, cultural, social and symbolic) interrelating to produce unequal outcomes. The field is the place where the competition for resources takes place. In this project, the field relates to two spaces: that of the Anglican parish, and that of the sphere of employment. What matters in each field will differ, and the rules will vary, but typically, certain individuals are betterable to mobilise the resources within a given field to produce an advantaged situation. This is because of their habitus - the dispositions an individual cultivates over a lifetime, rooted in early socialisation (Bourdieu 1984). How participants interacted with the Church (and the other fields they occupied) differed depending on their achieved habitus, the relative amounts of capitals accrued, and the status generated by those forms of capital.

Bourdieu (1991a) locates religion as a structural and institutional legitimiser of inequality. His theories on religion have been little-utilised in relation to social class (Rey 2008). This lacuna may have developed because it is not necessarily sociologists who have appropriated Bourdieu's writings on religion (McKinnon and Trzebiatowska 2011). Meanwhile class scholarship rarely references religion. This scholarly blind spot is not the whole story, however. Bourdieu's writings on religion and class appear rather divergent, as Dillon explains:

the totalizing, economistic frame he clamped on religious production offers a onesided and monolithic model of the religious symbolic economy, a view that contrasts with his more dynamic representation (e.g., Distinction) of lifestyle practices more generally. One of Bourdieu's many contributions has been to demonstrate the cultural differentiation within class groups... What is absent from Bourdieu's analysis of the religious economy is a similar sensitivity to the differentiated ways in which social contexts mediate and affect religious production. (Dillon 2001: 426) 
The term 'religious capital' that Bourdieu devised had much potential to help explain patterns of privilege in the religious field but as Dillon indicates, Bourdieu (1991a) was concerned with religious capital only insofar as it applied to religious professionals - the laity, it seems, were unable to possess religious capital. As Verter (2003) argues, Bourdieu's study is more aptly suited to the strict divides between priests and laity evident in the church monopolies of the Middle Ages, rather than applying to the context of contemporary religiosity. Although Bourdieu has produced more nuanced accounts of religion (e.g. Bourdieu 1987), where he recognises the interrelationship between priests and the laity, the usefulness of his theorisation has been questioned (Verter 2003). Indeed, Verter develops Bourdieu's restrictive notion of religious capital into the concept of spiritual capital which can be harnessed by all groups of people (not just clergy) and embodies 'Spiritual knowledge, competencies, and preferences' and can be 'valuable assets in the economy of symbolic goods' (2003: 152). Verter sees it akin to cultural capital in possessing three potential elements - the embodied, relating to the individual and their particular religious tastes and knowledge of religion (linked to socialisation); the objectified - the way the material and symbolic elements of religion, such as the theologies, objects and rituals, are imbued with prestige, evidenced through, for example, knowledge competencies around religious art, or knowing how to participate in a religious ritual; and the institutional - the way institutions become repositories of capital (such as the Church of England see Guest 2007; Guest et al. 2012).

From another angle, Lamont's (1992) starting point is how upper-middle-class men define value, and how certain boundary-making is deployed. She argues that Bourdieu's central concern with economic and cultural formations of boundary-making overshadows the importance of moral boundaries, which is especially pertinent to individuals situated within religious fields. Lamont's concern is not with religion per se (although religious participants allow her to map the significance of morality boundary-making within her sample), but her work, along with Verter's, indicates the importance of something akin to either spiritual capital or moral capital being deployed to potentially facilitate privilege. This article will use the insights of Verter and Lamont to analyse the extent to which various capitals (including spiritual capital) cultivate class privilege.

\section{The Emergence of the Clergy Husband}

Women started to be ordained in the Church of England as deacons in 1987 then as priests in 1994, and in the process, the clergy husband emerged. ${ }^{[1]}$ Becoming a priest precipitates great change, not only for those being ordained, but also for their families. Shifts can be greater than in other occupational settings, as the role impacts directly on the whole family (Page 2016). As clergy families are often required to live in church accommodation, they are automatically co-opted into church life (Greenbacker and Taylor 1991; Davies and Guest 2007). 
Priests operate according to a code of constant availability, obedience and life-long commitment - the role is therefore extremely demanding (Peyton and Gatrell 2013). Traditionally, a clergyman has required the services of his wife, not only to function in the private sphere as housekeeper and mother, but also to facilitate church work itself (Denton 1962; Finch 1980; Gill 1994; Murphy-Geiss 2011). Women's church-based voluntary work has a well-established history (Gill 1994). Given the community status accorded to clergy wives, this has entailed an expectation for them to facilitate volunteer activities such as leading women's and children's groups and teaching Sunday school (Douglas 1965; Finch 1980). This has been premised on demonstrating Christian goodness and virtue (Douglas 1965), and has therefore been a gendered role, with an expectation for wives to affirm their husbands' occupations. Indeed Finch (1980) argued that the clergy wife's role is institutionalised - refusal to engage would damage the credibility of her husband's work. The clergy wife role has traditionally been premised on so-called 'feminine' skills (e.g. cake-baking, flower arranging, social skills), embodying work deemed suitable for wives and not spouses (Finch 1983). Although historically there has been the opportunity for clergy wives to use their role to develop their public visibility and skills set, as women have entered paid work in greater numbers, the role of the clergy wife has often been experienced as burdensome and constraining (Greenbacker and Taylor 1991; Murphy-Geiss 2011). Analysing men's experiences can illuminate the negotiation of gender and class, especially in a context where the clergy spouse identity has been feminised.

\section{Studying Clergy Husbands}

Fourteen clergy husbands were interviewed from across England. Participants were recruited through Church of England officials, such as women's ministry advisors, who put me in contact with eligible participants. The men varied in age between 32 and 64, but most were at the upper end of this spectrum. Their wives were at different stages of ministry; some had been part of the first cohort to be ordained as priests; eight had been ordained more recently. All but one of the spouses had experienced life in church-owned accommodation. Their occupations varied, but in the main, pointed to privileged work-place identities, which, following Lamont (1992), I define as encompassing the requirement for university education, the ability to influence people and processes, and being in positions of considerable authority. These occupations spanned both professional and business spheres. Only two participants were engaged in manual occupations (a mechanic and manual worker), five had middle management and professional occupations (e.g. engineer, administrative manager) and, significantly, seven had leadership roles spanning professional and business spheres (e.g. managing director, senior doctor, senior academic). All participants were white. It is hard to know how 'typical' this sample was in relation to clergy husbands generally, as the Church gathers no statistics on spouses. However, based on the profile of priests, clergy are typically older, white and middle class (Thorne 2000; Walsh 2001; Peyton and Gatrell 2013), mirroring the composition of this sample. 
Interviews were semi-structured and in-depth allowing participants to elucidate their experiences. The topics included occupational backgrounds, the negotiation of paid and unpaid work, and integration into the Church as a spouse. Interviews were not deployed to reveal the 'truth' of participants' lives. Rather, as mediated accounts, interviews are understood to be situated events that capture life narratives at a given moment in time and space (Acker et al. 1991; Silverman 1993; May 2001; Lawler 2002; Hesse-Biber and Leavy 2006). Despite age and gender differences between interviewer and interviewees, I found participants willing to talk. Many narratives were of a candid nature; participants gave detailed and forthright accounts about how their wife's priesthood had impacted on their lives. Their honesty did not always paint them in a positive light. This level of disclosure could have resulted from the gender and age differences previously noted. They may have felt safer to disclose information in the presence of a young, female researcher. This also raises ethical questions about material that could negatively impact on participants, especially in specifying how their actions resulted in sustaining classed and gendered privilege. I have therefore tried to show the multi-dimensional aspects of these men's narratives: they were enormously proud and supportive of their wives and their achievements, but specificities of practice evidenced how their own advantaged social positions allowed them to retain much control in steering the lives of themselves and their families. Pease (2011) notes that privilege - the advantages, opportunities and entitlements attached to elevated social positions - is naturalised and made hidden, and this allows privilege to be legitimated. The task in hand here therefore was to carefully and sensitively unpack forms of privilege in order to further understand its reproduction.

Although data were gathered from a small number of participants, the accounts generated were in-depth, rich and nuanced, and gave particular insights into the management of classed and gendered identities. This study does not claim to be representative; it has captured data on clergy husbands from one religious tradition at a particular moment, and no claim is being made that the findings will relate to all spouses in all times and spaces. But the data helps illuminate much broader issues regarding the symbiotic relationship between religion, class and gender, which has hitherto been a neglected topic of study. Pseudonyms have been used throughout.

\section{Defining Class}

This project set out to explore the experiences of clergy husbands; it was not premised on examining social class. However, it quickly became evident that class was significant. Participants were not asked directly about social class (although they were asked about background, schooling and occupations). Social class is notoriously difficult to map; individuals can resist or hesitate in explicating a classed identity (Savage et al. 2001; McCloud 2009). Nevertheless, despite the difficulties, class can - and should - be mapped, in order that patterns of advantage and disadvantage can be ascertained (Taylor 2009). A persuasive classed understanding of these men's lives could be gleaned from their narratives, especially in relation to Bourdieu's (1984) four types of capital. Most 
participants were privileged in terms of economic capital. This was secured through esteemed occupational positions, which for the seven upper-middle-class spouses tended to be divided between highly-respected professional fields such as medicine and higher education, and elite business positions. In some cases wages enabled spouses to purchase particular economic assets, such as private schooling for children, seen as necessary if wives were posted in parishes where the local schools were deemed unsatisfactory. Participants put much emphasis on the notion of breadwinning, understood as a model where men take the lead in providing materially within heterosexual families. Although the breadwinner may be deemed old-fashioned, it remains a powerful ideology (Warren 2007). Retired participants could also generate status and economic security through generous pensions connected with previous employment.

One source of identity for participants was the type of house they lived in (Savage et al. 1992; Hamnett 1995). Many discussed having prestigious homes, e.g. period countryside properties or homes having a vast number of bedrooms (six bedrooms was quoted in one case). The significance of the home was all the more palpable as clergy are usually required to relinquish their own properties to move into church-owned accommodation. Despite imaginings of vicarages being vast, romantic piles, the reality was more sobering, as Tom, a 64 year old retired business consultant, explained:

I was absolutely devastated. We'd lived in that house for 21 years and I loved it. It was my dream house and I never thought we'd leave. The rectory that we moved into was modern, horrible, sixties, seventies modern, horrible; a nasty house.

The sense of loss was tangible for Tom, whose middle-class identity was bound up with previous ownership of his 'dream' home. His perception of the situation was determined by his prior experiences of living in an exclusive property. Colin, a 51 year old manual worker and one of only two working-class participants interviewed, had a different orientation to church property as he explained that it was actually better than his previous home, saying, the house 'was quainter and bigger because it had got three bedrooms'. Therefore, houses became something of a leveller among the clergy husbands, but their perceptions of church accommodation were understood through a classed lens.

Cultural capital strongly influenced the spouses' identities, and is embedded in some of the aforementioned ties regarding housing and education. The sense of cultural capital was accrued through privileged educational backgrounds that normally included university education, an ease in occupying middle-class spaces and particular taste preferences, for example, participation in elite sports (e.g., rugby), drama and choir groups. In contradistinction, working class participants emphasised a different set of cultural priorities. For example, Adrian, a 53 year old mechanic, emphasised his interest in leisure pursuits such as dog-racing and cinema-going.

Distinctions were also observed in terms of social capital, demonstrated through the different ways participants reacted to the church hierarchy. Whilst Edward, a 50 year old academic, discussed 
the ease with which he engaged the bishop's wife in conversation during the lunch queue at a church event, Colin, a manual worker, highlighted his anxiety when mixing with clergy, recalling one challenging episode where he felt he had embarrassed his wife, after asking the bishop which bishop he was (Colin's question was legitimate; a diocese will usually comprise of an overseeing diocesan bishop as well as supporting suffragan bishops). But this episode plagued Colin:

I must have embarrassed my wife - because that's her boss, basically. I basically didn't know who he was. And it came over as much as that.

Colin expressed a lack of confidence in social situations with middle-class participants, and felt ill-at-ease in knowing what to say and how to act. Bourdieu (1991b) notes how speech acts are embodied, and mediated through relations of power. The power to speak relies on having the authority to do so; Colin's habitus worked against him. He felt palpable differences in social statuses, which led him to question his own identity and where he fitted in.

These patterns highlighted the salience of class. The economic, cultural and social forms of classed identity fed into class as experienced at the symbolic level, evidenced through the prestige garnered through particular accents and professional statuses. These capital attributes corresponded with the habitus of the spouses. Although the habitus is constituted through socialisation, it is not static, but is reaffirmed and amended over time; middle-class participants were potentially able to not only confirm their habitus, but on becoming clergy spouses, could heighten and extend their middleclass habitus.

The main context of this research was the field of the Anglican parish. This is the field that is relevant to the clergy spouse, living in a house within the parish and encountering parishioners. By and large, the broader Church held little relevance to participants, unless the bishop happened to be visiting. Bourdieu was vague regarding what constituted a field (Bourdieu and Wacquant 1991); therefore, in determining the parish as the field in this instance, I am drawing on what is germane and significant from the viewpoint of the clergy husband. This does not mean that clergy spouses were wholly associated with the religious field; in fact, as we shall see, other fields were usually considered more important to them, such as their field of employment. For the clergy spouses, the religious field was only operationalised in certain contexts, although it did structure and impact many experiences, especially as they usually lived in a house provided by the Church.

\section{Privileged Employment: Cultivating Capitals}

Paid work was crucial in mediating clergy husbands' experiences. It was in this field that they had cultivated much prestige and honour. Participants in middle-class occupations had often attended university and experienced career success. The prestigious nature of a number of these occupations located men as part of a privileged stratum, where work brought enormous economic, social and 
cultural benefits. Being a breadwinner was a culturally-invested ideal among most participants (Warren 2007).

Parishioners, too, expected the clergy husbands to be breadwinners. For Sam, a 57 year old consultant, 'the assumption is that I'm out all day long earning the bread as it were'. For Tom:

They realised I was in an executive position in a large company and realised I wouldn't have any time to spare. There were plenty of men in the village who had similar types of jobs, so the parishioners understood my position in a way that they wouldn't quite have done [regarding] a woman's position.

Tom's paid work was congruent with the experiences of others living in this wealthy parish and corresponded with their attitudes and values. This was not only mediated through classed expectation, but also gendered expectation, and reduced any expectation to undertake church work. His employment was validated by parishioners; it was in synch with their own experiences and expectations of middle-class masculinity. This harmonisation was not always apparent, especially among clergy husbands who 'failed' to meet either gendered or classed expectations. Will, 32, was a full-time carer for his children, enabling his wife to manage a busy parish:

I think the role that was expected would be that I would work... I was at home looking after babies. Rather than at work bringing in money... there was surprise that I was going to stay at home... why didn't I work and then pay for a nanny?

Involved fathering, where fathers relinquish paid work, disrupts dominant masculinity ideals, which in this case, provoked critique from parishioners (Wall and Arnold 2007). It was certainly not the case that individuals in this parish expected mothers to be at home full-time, but rather it was normalised for couples to deploy external childcare, in order to enable both parents (and especially the father) to be employed. Paid work was given an elevated status; Will's decision to stay at home full-time therefore appeared deviant.

Meanwhile, Colin found it very difficult to fit in with the classed expectations of parishioners, given the contrast between his workspace and parish life:

I feel as though I'm not a typical vicar's spouse. Because at work I swear and say things that's contrary to [the church]... I feel in one sense I'm a misfit.

Colin's work-based identity was construed through particular behaviours - banter and swearing - which affirmed male camaraderie. Masculine competence was achieved through a particular kind of corporal work that emphasised physical strength, in a context where women were excluded. This environment contrasted significantly with parish life. The speech competencies 
expected in his workplace and in parish life were oppositional; Colin was anxious about saying the 'wrong' things. Whilst Colin's habitus was calibrated along working-class lines, entering a middleclass field meant that these were out of synch with each other; paid work and the clergy spouse role were not mutually supportive.

In sum, parishioners had gendered and classed expectations of clergy husbands. Those in well-paid middle-class jobs were viewed positively. Interviewees could also use their employment as leverage in negotiating their marital relationships. Graham, a 47 year-old managing director, underlined his breadwinning capabilities, emphasising that he earned three times more than his wife. Many prioritised their own work over their wife's. Edward's job determined the location of his wife's parish:

We can live anywhere in the Southern part of the diocese, so long as I can get to work. So I wasn't narrowing it down very much... there was an interesting job [300 miles away] she saw but didn't go for but I don't think that was just me, it was also the children.

Edward's work was taken as a given. It was never up for discussion whether he would renounce his esteemed job. Wives have traditionally been expected to relocate for the benefit of husbands, but when this is reversed, resistance ensues (Finch 1983; Savage et al. 1992).

Edward and Tom candidly explained that instead of adapting their work to make it more accommodating once their wives became priests, they had instead taken on more responsibility, thus making themselves less available. This resulted in Edward being 'busy and tired, which means I've been out more than I would have been and more inclined to slump and be grumpy', thus intensifying pressure on his wife, as she managed a new job, children and a 'grumpy' husband, reminiscent of Hochschild's (1997) triple burden of paid work, childcare/housework, and emotional labour.

Despite being outwardly supportive of his wife's vocation, Tom said:

Certainly to other people I would have been seen as very supportive of what she was doing. And I was very supportive... [but] truly, every time she asked... 'I'll need some more time for this', I took on a different job. A more demanding job in the company... I don't think it was deliberate; it just happened; opportunities came and I just took them without really sort of thinking about the implications for her.

Tom was enormously supportive and proud of his wife's achievements and was distressed when she encountered gender discrimination from individuals within the Church (e.g. from more senior colleagues). But at a personal level, his reactions were more complex, and indicated a subtle resistance to his changing domestic circumstances.

It appeared that their wives conceded, with little protest. Middle-class wives are encouraged to firstly prioritise their husband's job, then the family and finally their own employment (Hilbourne 
1999). Graham argued that 'I think she knows I've given up a lot to support her', so the wives had less occupational leverage in challenging their husbands' behaviour. Although wives' own social location was generally privileged in terms of class, education and ethnicity, they were meeting resistance from men utilising gender privilege (Hochschild 1997; Stone 2007).

Unsurprisingly, these men were not greatly involved in domestic tasks. When Graham was asked whether the running of the household was equitable, he responded:

I think she would say possibly not... But I do as much as I can... One thing about the vicar's role is that she does get some flexibility. So she can go shopping in a morning on her way to do a funeral. And I do come in at night and find the house has been cleaned... She's aware that I've got a lot on my plate.

Graham assumed his wife would be available to undertake domestic duties concurrently with her work as a priest. Doing food shopping prior to leading a funeral seems extraordinary - his definition of flexibility extended to significant events - and not merely mundane tasks. In other cases, spouses utilised their economic capital to facilitate domestic tasks. David, a 52-year old doctor said:

We get a cleaner in so that again is helped by me having a salary... Get somebody to do the garden. Again that's helped by my salary.

David made an explicit connection to the way his wages enabled this, prioritising his economic capability in subsidising those tasks traditionally assumed to be undertaken by wives.

Participants in manual occupations were far more likely to have modified their working patterns, indicating that those in middle- and upper-middle-class occupations were better-able to retain their current occupations (Connell 2005). Colin prioritised his wife's vocation by moving house and changing from a permanent job to agency work, so he could be fully flexible. Adrian, a mechanic, also altered his work because 'I knew [my employer] wouldn't have allowed me to move any greater distances'.

On becoming priests, participants' wives had embarked on a vocation that required much familial support. But participants in middle-class positions had successfully retained major elements of their working identities and resisted changes to the division of labour. The spouses most likely to alter their working practices were those who were younger (e.g. Will becoming a stay-at-home parent) and those from working-class backgrounds (e.g. Colin and Adrian who had both changed jobs). This indicates the extent to which the men were able to utilise classed and gendered privilege, buttressed through parishioner expectations.

\section{Spiritual Capital: Encountering the Field of the Anglican Parish}


Parishioner expectations emerged regarding spouses' engagement with church-based activities, especially in traditional parishes where expectations of clergy wives remained. Graham recalls the experience of arriving in a parish where controversy ensued over whether he should chair the Mother's Union - a role reserved for the 'wife' of the vicar. Colin said his gender 'confuses people'. But this 'confusion' could be cultivated to enable men to resist tasks that they did not want, as these quotes indicate:

I think they have less expectations of me as a man... if it was the other way round, [my wife] would be expected (Lloyd, technician, 57)

$[T]$ he nice thing is... you're not a clergy wife because that comes with a lot of baggage (Will).

Frank, a 57 year old retired manager, uncompromisingly informed parishioners that 'I don't do lots of baking; I don't look after the Sunday school. I don't run the Mother's Union'. The fact that spousal church work has been feminised also allowed men to resist their involvement. In another sense, participants' gender identity not only allowed them to opt out of tasks traditionally connected with the spouse of the priest, but could cultivate much prestige in its own right. Tom explained that he was 'called Mr Vicar in the village and I liked that. Because it gave me a role in the village that I wouldn't otherwise have had'. Being a clergy husband enabled Tom to generate even more merit than would be accorded a clergy wife - through gender privilege, Tom was elevated to be on par with the vicar herself. Removing 'spouse' from his identity, and utilising the privileged terminology of 'Mr' over the appendage of 'Mrs' (see Mills 1995), allowed the parishioners to boost his prominence, something Tom did not resist. The clergy husband role instituted a privileged status in its own right. Tom was pegging an identity onto a role that was readily available, giving him the opportunity to carve out a public presence in the community.

This proximity to the vicar was accompanied by expectations, and a realisation that the spouses themselves were co-opted into a religious field that they had to navigate. Michael, a 61 year old retired manager was aware that his behaviour would be watched, saying, 'I have to set an example - you drive at 30 miles an hour and don't pull out at junctions'. Being a clergy husband enhanced participants' visibility; within the context of the parish, their identities mattered. The narratives highlighted the persistence of a clergy spouse 'role' that the participants had to dismiss or embrace. Parishioners expected clergy husbands to embody a particular type of habitus, one that emphasised church-based middle-class masculinity. Middle-class Christian respectability was fostered through moral character-work, evidenced through church-based involvement (Lamont 1992). Possessing Anglican religiosity was assumed by parishioners. Husbands were marked out as being theologically adept and knowledgeable about religious matters. Sam said that parishioners expected from him the same competence as that accorded to the vicar: 
I think people would expect me to be supporting and kind of, you know, knowing as much about the job as it were as [my wife] would in terms of the spiritual side of it (Consultant, 57)

It was deemed entirely routine for Sam to formulate a men's ministry group; credentials pertaining to theological or pastoral training were not a requirement. His status as a clergy spouse enabled him to legitimately be a spiritual leader. Joseph too was fully engaged in his wife's work:

(T)he ministry team would involve both of us... the parishes really enjoyed this. A husband and wife were doing this together... if there was a pastoral problem, we'd share it and either I would go visiting or she would go visiting (Retired managing director, 57)

Despite not being ordained himself, Joseph utilised his status as a clergy spouse to cultivate a clergy-like role in enacting spiritual tasks with his wife. His competence in enacting this role was facilitated through his habitus, consolidated by active churchgoing, but also helped through his status as a (now retired) managing director. Taking up an authoritative position in relation to spiritual matters complemented his previous role in leading a workforce. But class was not the only factor. Women's religious leadership in the Church of England is relatively recent, and women have to continually prove their legitimacy (see Page 2011, 2014). Husbands enacting spiritual leadership reaffirms traditional associations between religious authority and masculinity and could therefore subtly disrupt and undermine the ministry of their wives.

Men's workplace identities aided their cultivation of spiritual capital; there was much congruence between the habitus deployed in both employment and church-based settings. The confidence generated through possessing management roles and having significant supervisory responsibilities enabled them to develop leadership roles in the church. Neither Sam nor Joseph commented extensively on their capabilities to undertake such spiritual tasks. Nothing in their habitus led them to question their proficiency. They were fish in water (Bourdieu and Wacquant 1992). But this level of comfort was brought into sharp disjuncture by working-class clergy husbands. Colin was acutely aware of the expectation to be theologically adept, but felt he did not meet these expectations: I'm not very good theologically. I see some clergy partners they're in there, they're working with their spouses. And I don't want to do that.

Colin saw clergy spouses being self-assured in the way they managed the role, and he felt inadequate. He cited his lack of university education as a stumbling block, and described the church as a place where the clergy were 'professional people'. He recognised that spiritual capital was something that he should possess - and he felt lacking that he did not have this in sufficient quantities. But in fact, Colin's narrative was replete with theological references. He eloquently theologised his own position in relation to Jesus' disciples, and even offered support to a trainee priest he encountered, also from a working-class background, who felt out of his depth. Therefore, Colin demonstrated ample pastoral skills and theological knowledge, but he did not recognise it as such, due 
to the way such endeavours are frequently coded in middle-class terms (see McKenzie, this special issue).

Some spouses tried to distance themselves from any perceived spiritual competence. Faith is usually assumed among clergy spouses (Douglas 1965) but spouses may not necessarily be religious (Greenbacker and Taylor 1991). Graham said, 'What [the Church] fail to realise is that while the spouse is supportive, they're not necessarily that religious'. Participants were successfully able to distance themselves from any sort of spiritual role. Graham reduced his church involvement to important services only, and spent little time contemplating how this would appear to the parish.

Other spouses cultivated the clergy spouse role to their advantage in bolstering their classed and gendered identity through church-based volunteering. Michael, a retired manager, relished the opportunity to perform church tasks:

It's practical satisfaction. And it's a complete contrast to what I was doing for a career... To get up to my elbows in muck, is quite relaxing... I shall be [at the church] tomorrow, helping rebuild a wall... But I pick and choose what I want to do.

Having performed managerial masculinity throughout his career, a newly-retired Michael now embraced the chance to demonstrate other 'masculinised' competencies such as building skills (Connell 2005). Embarking on retirement as a clergy husband fostered many opportunities to carve out a role that suited one's interests and pursuits. And despite this engagement with 'dirty work', Michael's middle-class identity was assured. In contrast, Edward distanced himself from manual tasks:

The areas the Church needs to grow in are not having more people to climb ladders... if I've got things to offer the Church... [it's] the music I'm doing.

Edward's skills and proficiencies were bound up not with church maintenance but with music. His involvement with manual tasks would be out of step with his own class habitus. This competency with music complemented his middle-class identity in a way that climbing ladders would not.

Spiritual capital took a number of forms. Some recoiled from any expectation to display theological competence and only a minority wanted to become a religious expert paralleling the competencies of their wife. Others displayed spiritual capital in a broader sense, through church volunteering. Even small amounts of church-work assured their status as a moral Christian in the eyes of parishioners (Lamont 1992). Extensive involvement was not expected, due to the aforementioned gendered expectation for participants to be in paid work. But working-class spouses found it harder to integrate into this middle-class milieu. In sum, clergy husbands could develop their role in a number of ways, and the greater the number of capital resources possessed, the better-able spouses were at developing it on their own terms. 


\section{Conclusion}

Participants recognised that there was a clergy spouse 'role' with which they had to engage, which on the surface sounds very limiting. But their gender and class privilege allowed them to define this on their own terms, even utilising the role to achieve new identities (pertinent for spouses who had recently retired).

For most clergy spouses, their habitus and associated capitals are conducive to the two main fields they experienced - the parish and the workplace. They experienced the parish as a field constituted through middle-class expectations, even if the parish was not in a middle-class area. The habitus cultivated in the middle-class workplace, fostered around authority, competence and prestige, complemented the expected habitus of the church, where middle-class male spouses were seen as an asset (e.g. in facilitating leadership roles). More specifically, the field of the parish was constituted through expectations for the cultivation of spiritual capital (Verter 2003). Displaying spiritual capital confirmed and validated one's status in the field. But by virtue of the role the clergy spouse occupied, husbands were not expected to 'prove' their spiritual capital to any great extent. Their proximity to the priest, and the unofficial role they occupied, enhanced further through their privileged gender, affirmed their spiritual capital credentials with little effort required, meaning that even those spouses who did not identify religiously were able to garner particular advantages from being the vicar's spouse. This is akin to the competency that Bourdieu (1984) says is accrued through titles and positions - competency is assumed through the occupation of an esteemed role. Being part of the vicarage not only allowed spouses to accrue status vicariously through their wives, but being clergy husbands rather than clergy wives consolidated their status further, thus allowing them, in some cases, to overshadow the status of the priest herself.

Crucial to the spouses' deployment of various capitals was their transferability. The capitals spouses accrued in the field of employment were deployed in the field of the parish, and vice versa (Bourdieu 1984; Verter 2003; Savage and Williams 2008). Spiritual capital had an important role to play. Verter (2003) argued that spiritual capital consisted of embodied, objectified and institutional dimensions. At an embodied level, spouses could use their level of comfort with Anglicanism to feel 'fish in water' within the parish. They could socialise with parishioners, converse with church leaders and 'instinctively' knew the embodied requirements of worship, even if they did not identify as particularly religious. Meanwhile, if they were religious, their embodied status as male clergy spouses enabled some to take up positions of spiritual leadership, in some instances, on an equal footing with their wives. Despite not being ordained themselves, spouses were able to convert leadership skills accrued in the field of employment into spiritual capital in the field of the parish. They displayed a 'natural' competency, validated through their status as middle-class men. Masculinity holds great currency in the Church of England (Nason-Clark 1987). Women have been traditionally excluded from holy orders; their entry to priesthood is historically recent, and only in the last few years has women's ordination to the episcopate been validated. Women's fight for inclusion generated much 
hostility, and this inclusion has been cultivated on unequal terms, especially surrounding the legal provisions historically made for those opposed to women priests (Furlong 1998; Maltby 1998; Page 2012).

Exclusionary mechanisms have also been embodied. Elsewhere I explore how Church clothing regimes disadvantage women and implicitly question women's authority as priests (Page 2014), and how pregnancy and motherhood disrupts embodied assumptions surrounding sacrality (Page 2011). Women's status in holy orders is fragile; the church leader is assumed to be male - and the male leader is assumed to be naturally more competent. Such gendered processes are not unique to the Church of course, and mirror many of the gendered inequalities occurring in other fields of employment (Acker 1990; Bagilhole 2002). But these similar processes within different fields help explain why the male clergy spouses displayed specific embodied competencies in their deployment of spiritual capital. Their experience as managers and directors in the field of employment was appropriated to convey their skill as leaders in the parish. Their lack of credentials was not questioned; their masculinity confirmed their suitability to the role, unsurprising in a Church culture that has sacralised masculinity (Nason-Clark 1987). This was premised on a particular sort of masculinity, as some participants found out to their cost. Church cultures have not only been gendered; they have also been classed. It is middle-class forms of masculinity that are validated and esteemed.

This leads us to consider Verter's second component of spiritual capital - its objectified dimension. This relates to how knowledge concerning particular objects and processes is harnessed for positive effect. Culturally, the Church of England is a repository of esteemed objects and processes, represented through the historical artefacts in its collection, such as the Mappa Mundi at Hereford Cathedral, or the Magna Carta at Salisbury Cathedral. The buildings themselves constitute revered architecture - the Gothic styles of York Minster or the Romanesque style of Durham Cathedral. Meanwhile, in terms of processes, these too are often esteemed - for example, the cathedral choirs, and their links to classical musical traditions. The carol service from King's College Chapel is annually broadcast on BBC2, affirming the Church's cultural links to elite institutions such as the University of Cambridge and the BBC. This all constitutes the Church as an institute of legitimation, which is emboldened to decide what formulations of culture are of value (Bourdieu 1984). This cultural status allowed clergy spouses to tap into the resources on offer, demonstrated through Edward's engagement with Church music. But this appropriation was premised on particular knowledge competencies - spouses had to be schooled to recognise the status of objects and processes, and have the knowledge to either talk about them or participate in them (e.g. Edward's participation was premised on his existing musical ability). This left working-class spouses - who often did not have this underpinning knowledge - at a significant disadvantage, and them feeling like they did not belong. The currency in which the church operated (based around competence in middleclass pursuits) made it hard for working-class spouses to participate; their legitimacy within this field was questioned. 
Verter's third dimension to spiritual capital relates to its institutional dimension - how institutions themselves become repositories of capital. This third dimension helps to further explain the currency of spiritual capital in fields outside of the Church, and how Anglican male clergy spouses were particularly positioned to benefit from its privileged status in broader society - a privilege which may not be replicated for male spouses in other religious traditions. Value is accrued through the eminent positioning of the Church of England, it having a legally and culturally privileged status vis-à -vis other denominations. How Anglicanism itself is constituted impacts on the extent to which privilege and advantage can be harnessed (Rey 2008). As Guest (2007: 187) argues, the dominance of the Church of England is bolstered through its connections to the British state, and conversely the state itself utilises 'the symbols and language of religious tradition as a means of sustaining legitimacy and respectability' (see also Guest et al. 2012). This positioning enabled participants' activities to be recognised and esteemed in fields beyond the Church itself (Rey 2008). This heightened status as an institute of legitimation (Bourdieu 1984) enabled spouses to utilise the Church as a repository of capital that was recognised, and therefore transferable to other fields.

Verter's three dimensions to spiritual capital help explain how male clergy spouses navigated status in the Church of England. But one missing component in his conceptualisation (absent also in Bourdieu's theorisation) is the role that morality plays, a dimension to capital that is explored in Lamont's (1992) work. Conveying moral authority was important in how spouses understood their identities as esteemed members of the parish. Their spiritual capital was conceptualised through displaying moral worth and good personhood. This was exemplified in numerous ways: through challenging inequality (Tom's anger at the gender inequality his wife experienced), donating their time to the church, even in tasks that would disrupt their links to middle-class status (e.g. Michael's church maintenance), and being an exemplary citizen. These activities generated esteem and praise, in different ways. But what was recognised as legitimate moral behaviour was classed and gendered. Despite Colin's good works, his working-class embodiment put him at a disadvantage in enabling his moral authority to be recognised. Will's role as an involved father was problematized by parishioners for challenging instituted gender norms. Whilst Colin and Will ultimately contested the ways in which moral authority was classified, this did not disrupt the unwritten and embedded moral codes that legitimated certain individuals and delegitimised others.

This article has explored the placement of religion in cultivating privilege. Anglicanism is a significant classed context that requires greater examination. For the participants, the symbolism generated through Anglican spaces allowed classed and gendered privilege to be naturalised. More research is needed to fully explain the Anglican Church's relationship to class identity and class formation and the role religion plays more broadly in forging privileged outcomes.

\section{Acknowledgements}


The research would not have been possible without the participants, as well as the gatekeepers who facilitated access. I also thank the ESRC for funding this project (Award numbers PTA-031-200400290 and PTA-026-27-2911), the two anonymous reviewers for encouraging me to push my analysis further, and members of the Class and Christianity symposium (notably, Jo McKenzie for her sterling advice and Mathew Guest and Yvette Taylor for their insightful comments).

\section{Notes}

${ }^{1}$ The numbers of women ordained in the Church of England have risen over the years, whereas the numbers of men ordained has decreased. In 2002, women comprised around $20 \%$ of diocesan clergy; by 2012, this had risen to 32\% (Church of England Statistics for Mission 2012).

\section{References}

ACKER, J. (1990) 'Hierarchies, Jobs, Bodies: A Theory of Gendered Organizations' In: Gender and Society 4 (2) p. $139-158$.

ACKER, J., K. BARRY, \& ESSEVELD, J. (1991) 'Objectivity and Truth: Problems in Doing Feminist Research' In: FONOW, M. M. \& COOK, J. A. (eds) Beyond Methodology: Feminist Scholarship as Lived Research Indianapolis, Indiana University Press.

BAGILHOLE, B. (2002) Women in Non-Traditional Occupations Basingstoke, Palgrave Macmillan. BOURDIEU, P. (1984) Distinction: A Social Critique of the Judgment of Taste London, Routledge.

BOURDIEU, P. (1987) 'Legitimation and Structured Interests in Weber's Sociology of Religion' In: LASH, S. \& WHIMSTER, S. (eds) Max Weber, Rationality and Modernity London, Allen \& Unwin.

BOURDIEU, P. (1991a) 'Genesis and Structure of the Religious Field' In: Comparative Social Research 13 p. 144.

BOURDIEU, P. (1991b) Language and Symbolic Power Cambridge, Polity Press.

BOURDIEU, P. \& WACQUANT, L. (1992) An Invitation to Reflexive Sociology Cambridge, Polity Press.

CHURCH OF ENGLAND. (2012) Statistics for Mission 2012: Ministry London, The Archbishops' Council. Available at:https://www.churchofengland.org/media/1868964/ministry\%20statistics\%20final.pdf (accessed $19^{\text {th }}$ January 2017).

CONNELL, R. W. (2005) Masculinities Cambridge, Polity Press.

DAVIES, D. \& GUEST, M. (2007) Bishops, Wives and Children: Spiritual Capital Across the Generations Aldershot, Ashgate.

DENTON, W. (1962) The Role of the Minister's Wife Philadelphia, The Westminster Press.

DILlON, M. (2001) 'Pierre Bourdieu, Religion and Cultural Production' In: Cultural Studies, Critical Methodologies 1 (4) p. 411-429. 
DOUGLAS, W. (1965) Ministers' Wives New York, Harper \& Row.

FINCH, J. (1980) 'Devising Conventional Performances: The Case of Clergymen's Wives' In: Sociological Review 28 (4) p. 851-870.

FINCH, J. (1983) Married to the Job London, George Allen \& Unwin.

FURLONG, M. (1998) 'Introduction: Act of Synod - Act of Folly?' In: FURLONG, M. (ed) Act of Synod - Act of Folly? London, SCM Press.

GILL, S. (1994) Women and the Church of England London, SPCK.

GREENBACKER, L. \& TAYLOR, S. (1991) Private Lives of Ministers' Wives Far Hills New Jersey, New Horizon Press.

GUEST, M. (2007) 'In Search of Spiritual Capital: The Spiritual as a Cultural Resource' In: FLANAGAN, K. \& JUPP, P (eds) A Sociology of Spirituality Aldershot, Ashgate.

GUEST, M., OLSON, E. \& WOLFFE, J. (2012) 'Christianity: Loss of Monopoly In: WOODHEAD, L. \& CATTO, R. (eds) Religion and Change in Modern Britain London, Routledge.

HAMNETT, C. (1995) 'Home-ownership and the Middle Classes' In: BUTLER, T. \& SAVAGE, M. (eds) Social Change and the Middle Classes London, UCL Press.

HESSE-BIBER, S. \& LEAVY, P. L. (2006) The Practice of Qualitative Research London, Sage.

HILBOURNE, M. (1999) 'Living Together Full Time? Middle-class Couples Approaching Retirement' In: Ageing and Society 19 (2) p. 161-183. [doi:10.1017/s0144686x99007230]

HOCHSCHILD, A. R. (1997) The Time Bind New York, Henry Holt and Company.

LAMONT, M. (1992) Money, Morals and Manners Chicago, University of Chicago

Press. [doi:10.7208/chicago/9780226922591.001.0001]

LAWLER, S. (2002) 'Narrative in Social Research' In: MAY, T. (ed) Qualitative Research in Action London, Sage.

MALTBY, J. (1998) 'One Lord, One Faith, One Baptism, but Two Integrities?' In: FURLONG, M. (ed) Act of Synod - Act of Folly? London, SCM Press.

MAY, T. (2001) Social Research: Issues, Methods and Process Maidenhead, Open University Press.

MCCLOUD, S. (2009) 'The Ghost of Marx and the Stench of Deprivation: Cutting the Ties that Bind in the Study of Religion and Class' In: MCCLOUD, S. \& MIROLA, W. A. (eds) Religion and Class in America Leiden, Brill.

MCKINNON, A. \& TRZEBIATOWSKA, M. (2011) 'Bourdieu, Capital, and Conflict in a Religious Field: The Case of the "Homosexuality" Conflict in the Anglican Communion' In: Journal of Contemporary Religion 26 (3) p. 355-370.

MCMINN, M. R., LISH, R. A., TRICE, P. D., ROOT, A. M., GILBERT, N., \& YAP, A. (2005) 'Care for Pastors: Learning from Clergy and their Spouses' In: Pastoral Psychology 53 (6) p. 563-

581. [doi:10.1007/s11089-005-4821-y]

MELLOW, M. (2007) Defining Work: Gender, Professional Work, and the Case of Rural Clergy Montreal \& Kingston, McGill-Queen's University Press.

MILLS, S. (1995) Feminist Stylistics London, Routledge. 
MURPHY-GEISS, G. E. (2011) 'Married to the Minister: The Status of the Clergy Spouse as Part of a TwoPerson Single Career' In: Journal of Family Issues 32 (7) p. 932-955.

NASON-CLARK, N. (1987) 'Are Women Changing the Image of Ministry? A Comparison of British and American Realities' In: Review of Religious Research 28 (4) p. 330-340. [doi:10.2307/3511638]

PAGE, S. (2011) 'Negotiating Sacred Roles: A Sociological Exploration of Priests who are Mothers' In: Feminist Review 97 (1) p. 92-109.

PAGE, S. (2012) 'Femmes, Mères et Prêtres dans l'Église d'Angleterre: Quels Sacerdoces' In: Travail, Genre et Sociétés 27 p. 55-71. [doi:10.3917/tgs.027.0055]

PAGE, S. (2014) 'The Scrutinised Priest: Women in the Church of England Negotiating Professional and Sacred Clothing Regimes' In: Gender, Work and Organization 21 (4) p. 295-307.

PAGE, S. (2016) 'Double Scrutiny at the Vicarage: Clergy Mothers, Expectations and the Public Gaze' In: REIMER, V. (ed) Angels on Earth: Mothering, Religion and Spirituality Bradford, Canada, Demeter Press.

PEASE, B. (2011) Undoing Privilege London, Zed Books.

PEYTON, N. GATRELL, C. (2013) Managing Clergy Lives: Obedience, Sacrifice, Intimacy London, Bloomsbury.

REY, T. (2008) Bourdieu on Religion London, Equinox Publishing.

SAVAGE, M., BAGNALL, G, \& LONGHURST, B. (2001) 'Ordinary, Ambivalent and Defensive: Class Identities in the Northwest of England' In: Sociology 35 (4) p. 875-

892. [doi:10.1177/0038038501035004005]

SAVAGE, M., J. BARLOW, P. DICKENS \& FIELDING, T. (1992) Property, Bureaucracy and Culture:

Middle-Class Formation in Contemporary Britain London, Routledge.

SAVAGE, M. \& WILLIAMS, K. (2008) 'Elites: Remembered in Capitalism and Forgotten by Social Sciences' In SAVAGE, M. \& WILLIAMS, K. (eds) Remembering Elites Oxford, Blackwell

Publishing. [doi:10.1111/j.1467-954x.2008.00759.x]

SILVERMAN, D. (1993) Interpreting Qualitative Data Methods for Analysing Talk, Text and Interaction London, Sage.

STONE, P. (2007) Opting Out? Why Women Really Quit Careers and Head Home Ewing, NJ, University of California Press.

TAYLOR, Y. (2009) Lesbian and Gay Parenting: Securing Social and Educational Capital Basingstoke, Palgrave MacMillan.

THORNE, H. (2000) Journey to Priesthood Bristol, Centre for Comparative Studies in Religion and Gender.

VERTER, B. (2003) 'Spiritual Capital: Theorizing Religion and Bourdieu against Bourdieu' In: Sociological Theory 21 (2) p. 150-174.

WALL, G. \& ARNOLD, S. (2007) 'How Involved is Involved Fathering? An Exploration of the Contemporary Culture of Fatherhood' In: Gender \& Society 21 (4) p. 508-527. [doi:10.1177/0891243207304973]

WALSH, C. (2001) Gender and Discourse Harlow, Longman. 
WARREN, T. (2007) 'Conceptualizing Breadwinning Work' In: Work, Employment \& Society 21 (2) p. $317-$ 336. [doi:10.1177/0950017007076642] 